\title{
Comparison of the Porosity of Aluminum Alloys Castings Produced by Squeeze Casting
}

\author{
Andrzej Zyska (0000-0001-9307-4364), Kinga Boroń (0000-0002-8421-3745) \\ Czestochowa University of Technology, Department of Metallurgy and Metal Technology, Al. Armii Krajowej 19, \\ 42-200 Częstochowa, Poland. E-mail: andrzej.zyska@pcz.pl, kinga.boron@pcz.pl
}

The results of researches on porosity and structure of castings from AlMg9, AlSi7Mg and AlCu4Ti alloys produced by squeeze casting and for comparison by gravity die casting are presented. The tests were carried out on 200x100x $25 \mathrm{~mm}$ plates squeeze casted under 90MPa pressure. Prior to the commencement of experimental studies, numerical simulations of solidification were made for the selected alloy (AlSi7Mg) in order to determine the potential locations of shrinkage porosity. As part of the study, the porosity distribution in the plate cast was assessed by taking samples for measurements from the center and edge of the casting. It was found that the area particularly vulnerable to the presence of shrinkage porosity is the central part of the casting and the zone extending from its center to the upper surface. Due to the wide temperature range of solidification of the examined alloys, diffused porosity occurs in castings, and the shape of the pores formed is conditioned on the solidification morphology. The average porosity of squeeze castings is two times smaller than gravity die castings and is at the level of 1.0-1.5\% depending on the type of alloy. In addition, as a result of pressing, the shrinkage porosity in the central part of the plate is reduced and its distribution becomes uniform throughout the volume. High pressure acting on solidifying castings ensures a significant increase of grains density in microstructure and decrease of SDAS.

Keywords: Squeeze Casting, Aluminum Alloys, Porosity, Structure

\section{Introduction}

Squeeze casting method is a technology that combines three methods such as forging, pressure casting and die casting. Thanks to the combination of these methods, the metal solidifies under pressure, which in turn results in a significant improvement in the properties of castings [1,2]. This technology is designed for casting of light metals, especially aluminum alloys due to the good properties obtained with the alloys cast with this method. Squeeze casting in terms of quality is more effective than high pressure die casting and die casting, while economically is better than forging. Comparing the squeeze casting technology for high pressure die casting, there are several significant differences in the quality of castings. The development of the squeeze casting technology allowed to make casts with negligible shrinkage and gas porosity, fine-crystalline structure and high tightness of castings. This is conditioned by the fact that in comparison to die casts, the pressure affecting the liquid metal causes accelerated heat exchange, thus eliminating the air gap at the contact point of the casting and mould, and creates permanent contact between the molten metal and the mould surface [3]. Thanks to the use of external pressure in the squeeze casting method during solidification of the metal, noticeable improvement of strength parameters of castings can be observed. These casts are characterized by an increase in the yield point of $10-15 \%$ and an improvement in overall elongation by $50-80 \%$, dimensional accuracy is $0.25 \mathrm{~mm}$ for casting a length of $100 \mathrm{~mm}$ and $0.6 \mathrm{~mm}$ for the casting of 500 $\mathrm{mm}$ [4-6]. Castings produced by this method are also characterized by a smooth surface, no surface defects and a shape very similar to the final product. The costeffectiveness of the process is also associated with the fact of lower energy and material consumption, even up to $98 \%$ of molten metal, by eliminating the gate assembly, strain relief and feeding head [7]. Due to the lack of a running gate system and limited flow of liquid metal, even low-castability plastic alloys can be used in this method, however, it can not be too small, because it leads to casting defects such as cold laps [8,9]. However, one of the most important advantages of the squeeze casting technology compared to pressure casting is to enable complete heat treatment of castings [10-12]. Applying pressure at a temperature close to the solidify point is the most effective. The highest growth rate of nucleation and the maximum undercooling of the alloy occur then. On the other hand, too much overheating can almost completely disrupt the effect of elevated pressure [3,4,13-17].

In the literature, one can find various theories about what factorinfluences the fragmentation of the structure in castings made with the squeeze casting 
method. It can be generally stated that the improvement of mechanical properties and the reduction of grain size depends on: undercooling of molten metal, heat transfer coefficient, composition and fraction of forming phases during solidification $[4,18]$. It should be noted, however, that the mechanical properties and structure of castings produced by squeeze casting as well as by gravity depend on a number of other factors such as the wall thickness of the castings, the geometry of the gate and pouring system, the combination of micro-alloys, modifications, etc [19-22]. In order to obtain high-quality aluminum castings, Senthil et al. [23] adapted the genetic algorithm and the Taguchi method to analyze the direct squeeze casting process. They have stated that castings obtained in optimal pressing parameters revealed superior grain refinement in microstructure and 65\% higher tensile yield strength compared to gravity die castings. The application of pressure during solidification also causes a significant reduction in the space between the secondary arms of dendrites. The prediction of SDAS in squeeze cast alloys based on fuzzy logical methods was presented by Patel et al. [24]. The developed models have shown good performance and can be used to predict SDAS in squeeze casting.

The aim of the presented research was to assess the porosity of castings of AlSi7Mg, AlMg9 and AlCu4Ti alloys produced in the squeeze casting technology in comparison to gravity casting.

\section{Methodology and materials used for the study}

Three standardized (according to PN-EN 1706:2001) aluminum alloys were used for testing: AlMg9, AlSi7Mg and AlCu4Ti with the chemical composition presented in Table 1.

Tab. 1 Chemical composition of tested aluminum alloys

\begin{tabular}{|c|c|c|c|c|c|c|c|c|c|}
\hline \multirow{2}{*}{$\begin{array}{l}\text { Alloy } \\
\text { EN AC- }\end{array}$} & \multicolumn{9}{|c|}{ Chemical composition, $\%$} \\
\hline & $\mathrm{Si}$ & $\mathrm{Mg}$ & $\mathrm{Cu}$ & Ti & $\mathrm{Be}$ & Mn & $\mathrm{Zn}$ & $\mathrm{Fe}$ & $\mathbf{A l}$ \\
\hline AlMg9 & 0.30 & 9.35 & 0.01 & 0.01 & 0.07 & 0.10 & 0.08 & 0.21 & Balance \\
\hline AlSi7Mg & 7.20 & 0.37 & 0.18 & 0.01 & - & 0.35 & 0.17 & 0.60 & Balance \\
\hline $\mathrm{AlCu} 4 \mathrm{Ti}$ & 0.35 & 0.03 & 4.27 & 0.15 & - & - & 0.11 & 0.05 & Balance \\
\hline
\end{tabular}

Prior to experimental studies, numerical simulation of solidification was carried out in the NovaFlow\& Solid program in order to identify potential places of contraction porosity in the analyzed slab casting. In foundry industry, this program is used to simulate the flow of liquid metal in the pouring system and the mold cavity, and to simulate the solidification of castings. Due to the specificity of the squeeze casting

a)

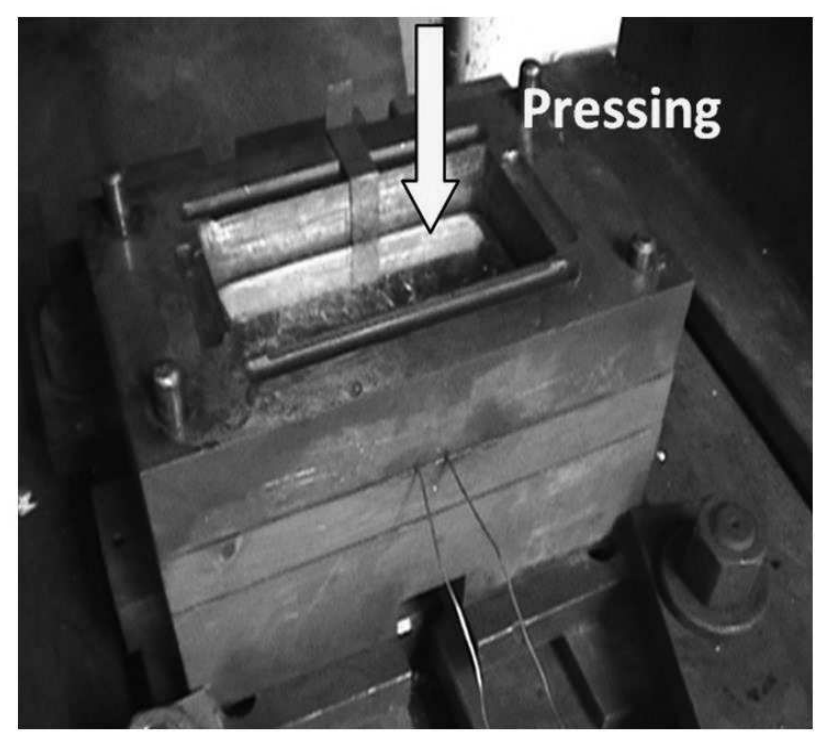

method, the focus was only on thermal (heat) issues and the flow of liquid metal was omitted. Simulations were also limited to AlSi7Mg alloy solidification analysis, because in the case at hand the occurrence of places exposed to shrinkage porosity is mainly determined by the casting geometry and, to a lesser extent, by the type of aluminum alloy.

b)

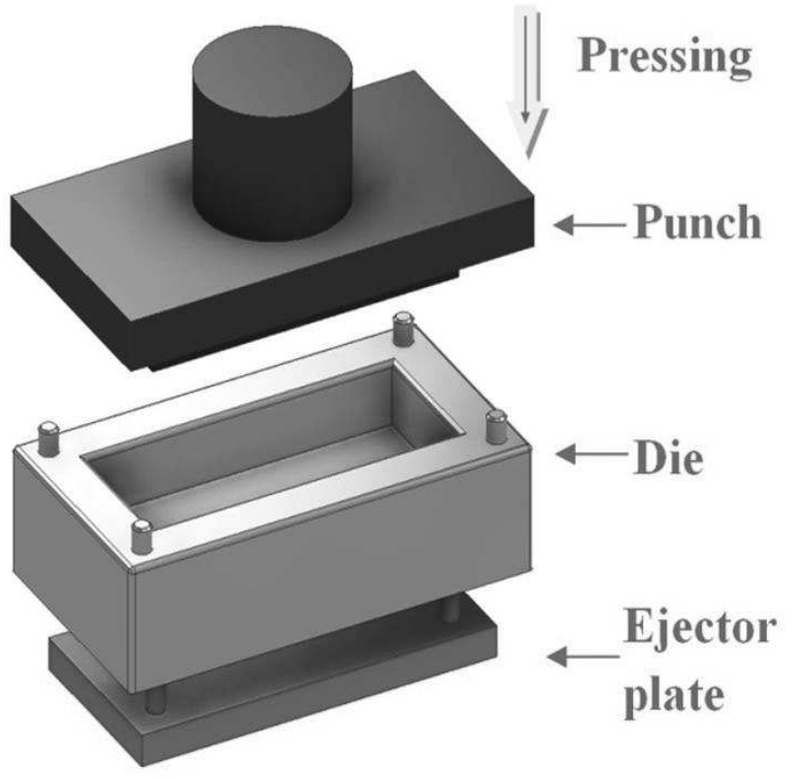

Fig. 1 The lower part of the metal mould used in research a), scheme of the pressing system b) 
A medium frequency crucible induction furnace PIT50S/400 with a capacity of $20 \mathrm{dm}^{3}$ was used to melt the metal charge. Slab-shaped castings measuring 100x200x $25 \mathrm{~mm}$ were produced by pressing in the squeeze casting and by gravity method.The hydraulic press PHM-250c was applied for the squeeze casting process, which was equipped with a metal mould (die) with the dimensions of $100 \times 200 \times 50 \mathrm{~mm}$ recess and the ejector slab.

The pressing started from heating the mould to about $200^{\circ} \mathrm{C}$ and covering it with a protective, insulating and lubricating layer of colloidal graphite solution in water. The lower part of the metal mold with NiCr$\mathrm{NiAl}$ thermocouples installed in the heat center of the casting and in the die is shown in Figure 1. Next, a portion of about $1350 \mathrm{~g}$ of molten metal was taken from the furnace crucible with the casting ladle and poured into the lower part of the die. The overheating temperatures of the tested alloys after pouring into the mould was about $50-80^{\circ} \mathrm{C}$ above liquidus temperatures (Tab. 2).Subsequently, the punch was lowered and the metal pressed. The pressing was carried out using a pressure of $90 \mathrm{MPa}$ and the time of impact of the punch on the casting 30 seconds. After that time the upper part of the die was lifted up and the casting was ejected by four ejector pins placed in the corners of the slab. The parameters of the squeeze casting process were determined on the basis of previous study $[7,13]$, in which the effect of applied pressures during casting on the tensile strength and solidification of aluminum castings was analyzed. The samples for strength tests were taken in the same way as the internal sample presented in Fig. 3. Diagram illustrating the entire squeeze casting process is shown in Figure 2. Characteristic temperatures of the process: alloys overheating temperatures, temperatures at which metal pressing began, and equilibrium liquidus temperatures determined in the ThermoCalc program are shown in Table 2.

Tab. 2 Characteristic temperatures of the process

\begin{tabular}{|c|c|c|c|c|}
\hline $\begin{array}{c}\text { Alloy } \\
\text { EN AC- }\end{array}$ & $\begin{array}{c}\text { Overheating temper- } \\
\text { atures, }{ }^{\circ} \mathrm{C}\end{array}$ & $\begin{array}{c}\text { Pressing start tem- } \\
\text { peratures, }{ }^{\circ} \mathrm{C}\end{array}$ & $\begin{array}{c}\text { Equilibrium liquidus } \\
\text { temperatures, }{ }^{\circ} \mathrm{C}\end{array}$ & $\begin{array}{c}\text { Pressing end temper- } \\
\text { ature, }{ }^{\circ} \mathrm{C}\end{array}$ \\
\hline $\mathrm{AlMg} 9$ & $683 \pm 8$ & $623 \pm 5$ & 614 & $400 \pm 25$ \\
\hline $\mathrm{AlSi} \mathrm{Mg}$ & $681 \pm 14$ & $628 \pm 6$ & 617 & $400 \pm 25$ \\
\hline $\mathrm{AlCu} 4 \mathrm{Ti}$ & $717 \pm 12$ & $661 \pm 4$ & 651 & $450 \pm 30$ \\
\hline
\end{tabular}

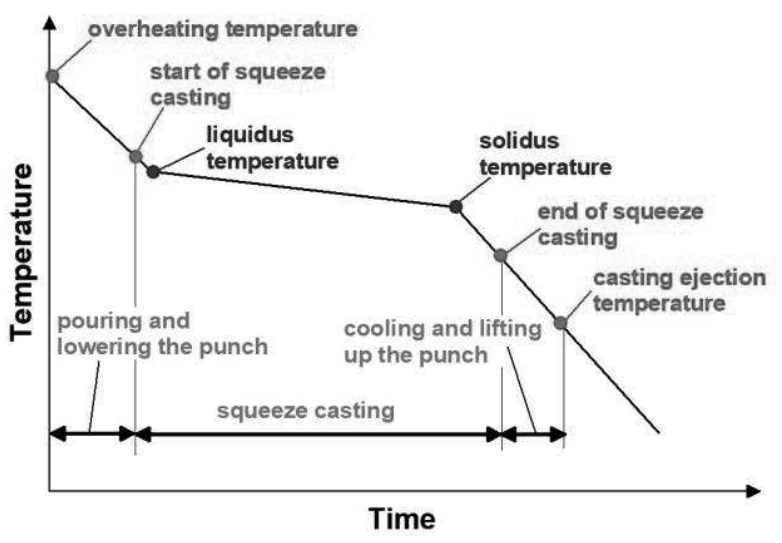

Fig. 2 Diagram illustrating the squeeze casting process

Using a die mounted on a hydraulic press, castings were also made by gravity (without pressure). Gravitational casting consisted in pouring a liquid alloy into the lower part of the mould. When the metal surface came into contact with the surface of the press stamp, the stamp was stopped and the hydraulic system was turned off. After cooling the castings samples were taken to measure the porosity. A total of 24 slab shape castings were tested, making 4 castings from each alloy using gravity and 4 castings by direct compression.

Two samples in the shape of cuboid $25 \times 25 \times 100$ $\mathrm{mm}$ were taken from each casting. In order to analyze the distribution of porosity in the casting, the samples were cut from the center of the plate (internal samples) and from its edge along the shorter side (external samples). Scheme of cutting out samples from a casting plate is shown in Figure 3.

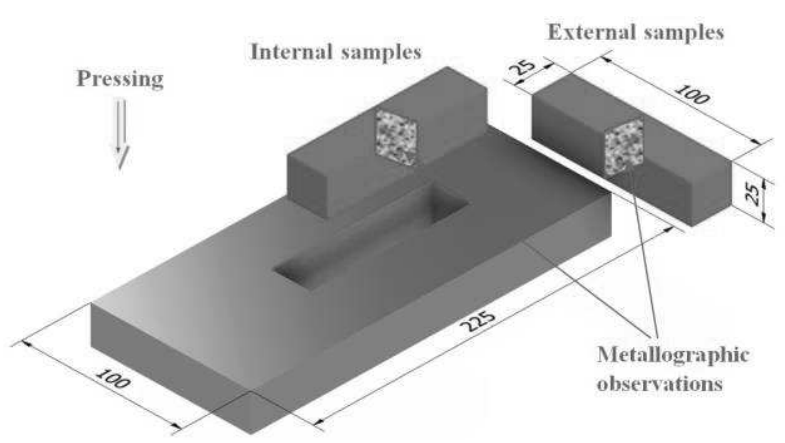

Fig. 3 Scheme of cutting out samples from a casting plate and sampling places for microstructure testing

The porosity assessment was carried out using the hydrostatic weighing method according to the BN75/4051-10 standard. All samples were weighed in air and water, and their density was determined based on:

$$
\rho_{P}=\frac{m_{1}}{m_{1}-m_{2}} \cdot \rho_{W}\left[\mathrm{~kg} \cdot \mathrm{m}^{-3}\right],
$$

Where:

$\rho_{\mathrm{P}}-$ sample density, $\mathrm{m}_{1}-$ sample weight in air; $\mathrm{m}_{2}-$ sample weight in water; $\rho_{\mathrm{W}}-$ water density.

Next, the porosity of the tested samples was calculated 
using the compound:

$$
P=(1-L G) \cdot 100 \%[\%],
$$

Where:

LG - the so-called 'gas number' determined by the expression $L G=\rho_{\mathrm{P}} / \rho_{\mathrm{TS}}, \rho_{\mathrm{T} \mathrm{S}}$ - theoretical density of the alloy

The theoretical density of the alloy determines the relationship:

$$
\rho_{T S}=\frac{100}{\frac{A}{\rho_{T A}}+\frac{B}{\rho_{T B}}+\ldots+\frac{N}{\rho_{T N}}}\left[\mathrm{~kg} \cdot \mathrm{m}^{-3}\right],
$$

Where:

$A, B, N$ - content of individual components in $\%$ by mass, $\rho_{T A}, \rho_{T B}, \rho_{T N}-$ theoretical density of individual alloy components

After measurements of porosity were taken from internal and external samples, metallographic specimens were made and microstructural observations of

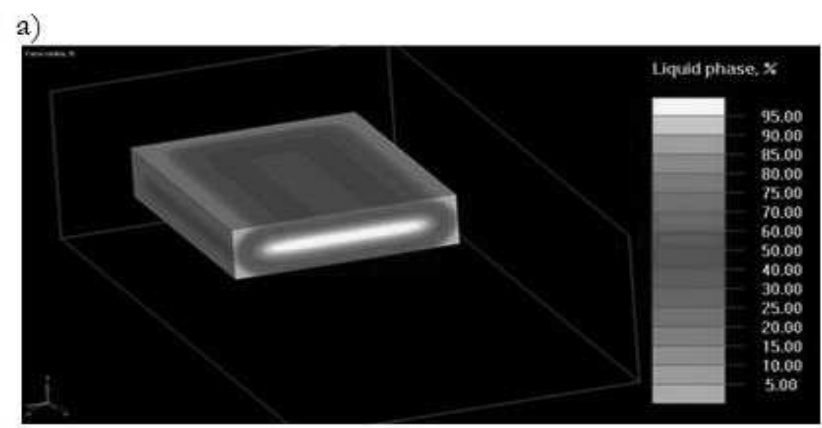

c)

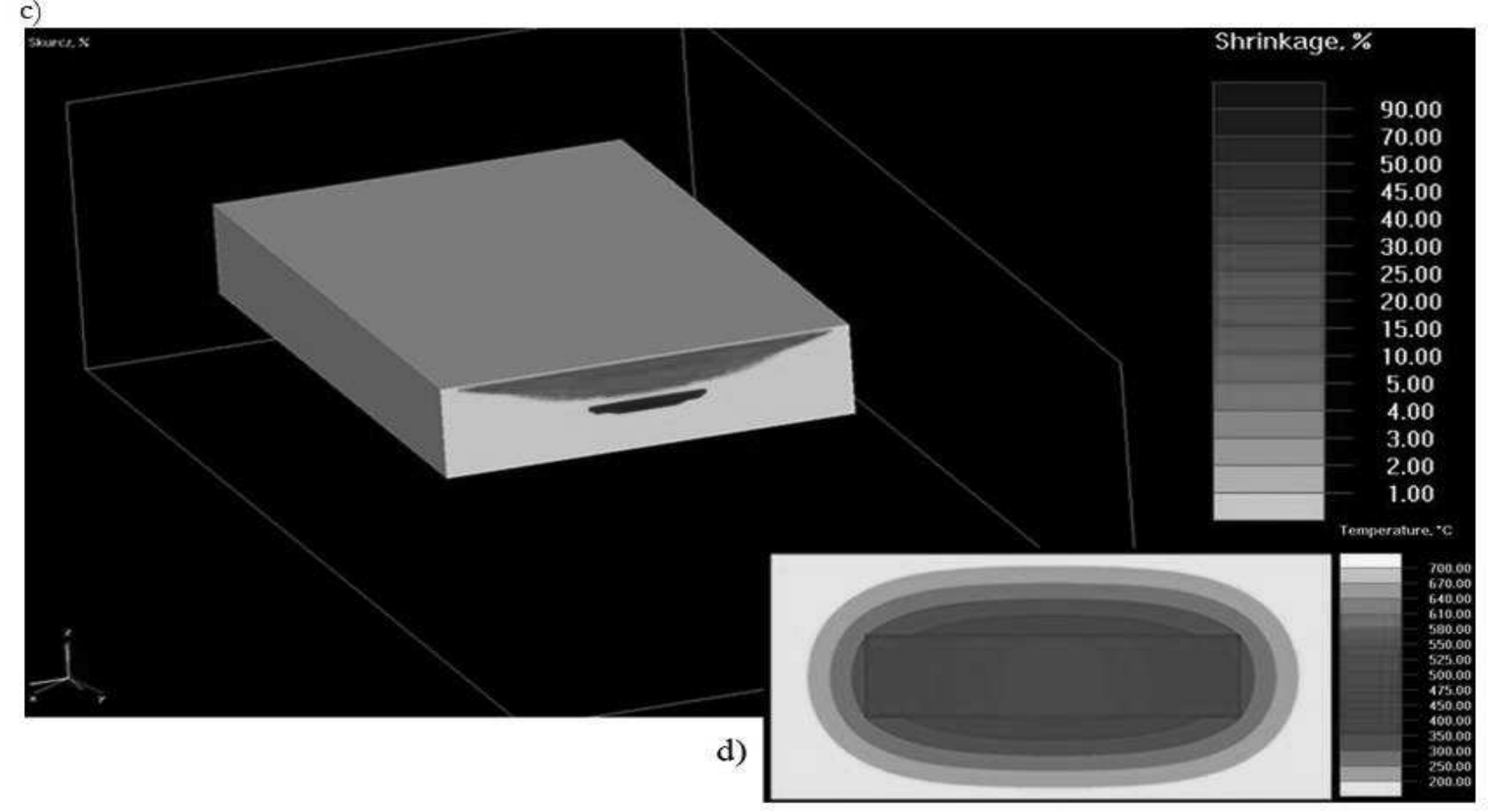

Fig. 4 The results of numerical simulations of solidification of the AlSi7Mg alloy casting plate: a) field of liquid phase participation in the middle period of solidification - isometric view, b) field of liquid phase participation in the final solidification phase - residual liquid - view in the transparency, c) 3D distribution of shrinkage in the casting after solidification, d) temperature field in the cast of the slab and metal mould after solidification - 2D view the tested alloys were carried out.

\section{Test results}

\subsection{Numerical simulation of solidification}

The basic simulation of solidification was carried out in the SOLIDIFICATION module with the following initial conditions: temperature of the liquid alloy $720^{\circ} \mathrm{C}$ (homogenous for the entire cast), mould temperature $200^{\circ} \mathrm{C}$, mould material - carbon steel. At the cast-mould surface, the boundary condition of the fourth type was adopted. The computational domain was discretized per 1236492 unit cells with a characteristic dimension of a single cell $1.4 \mathrm{~mm}$. A minimal mould thickness of $30 \mathrm{~mm}$ was assumed for the calculations. Figures $4 \mathrm{a}-4 \mathrm{~d}$ present the results of numerical simulations illustrating: the area of the liquid phase contribution in the middle period of solidification, the liquid phase share in the final solidification phase - residual liquid, 3D distribution of the shrinkage in the casting and the temperature field in the casting and mould after solidification. b)

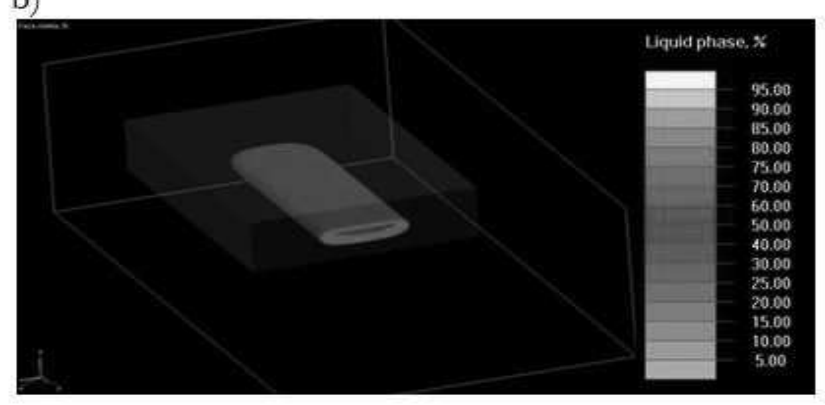


The analysis of these quantities allows the identification of heat centers and determination of potential places of shrinkage porosity in the casting. On the basis of Figure $4 a$, it can be seen that the casting is the fastest in the corners, on the edges and on the outer walls of a smaller area. This is the result of the fastest heat dissipation from these places. In the present moment of solidification ( 3 s from flooding the mould), the average proportion of liquid phase in the casting is about $55 \%$, while in the boundary layers it is $5 \%$ and in the middle part $95 \%$. The distribution of the residual liquid in the casting shown in Figure $4 \mathrm{~b}$ reveals the area particularly exposed to shrinkage porosity. This drawing as well as figures $4 \mathrm{c}$ and $4 \mathrm{~d}$ indicate that the shrinkage effects will mainly be concentrated in the middle of the slab, and may also include an area tapering from the top surface of the slab to the center.

The central part of the cast gives off the heat for the longest time and solidifies last. Lack of liquid metal supply to this part of the casting results in the formation of a longitudinal void with a dimension of approx. $23 \times 2.5 \times 85 \mathrm{~mm}$. Due to the wide temperature range of solidification of the AlSi7Mg alloy as well as other Al alloys, dispersed porosity (shrinkage porosity) should be expected in this part of the casting. Numerical simulations also show that the total solidification time of the casting is $24 \mathrm{~s}$, and the maximum temperature difference between the center and the edge of the plate is about $100^{\circ} \mathrm{C}$. The overheating zone of the metal mold up to $300^{\circ} \mathrm{C}$ in one casting production cycle is at the level of $150 \mathrm{~mm}$.

\subsection{Porosity and structure}

The results of porosity tests determined by the hydrostatic weighing method for gravity and squeeze casting aluminum alloy castings are summarized in Table 3. Figures 5-7 show the average porosity of internal and external samples and the average porosity of plate castings produced in both technologies.

Tab. 3 Results of porosity measurements in gravity and squeeze cast samples

\begin{tabular}{|c|c|c|c|c|c|c|}
\hline \multirow{3}{*}{ Alloy } & \multicolumn{6}{|c|}{ Porosity, $\%$} \\
\hline & \multicolumn{3}{|c|}{ Gravity casting } & \multicolumn{3}{|c|}{ Squeeze casting } \\
\hline & $\begin{array}{l}\text { Internal } \\
\text { samples }\end{array}$ & $\begin{array}{l}\text { External } \\
\text { samples }\end{array}$ & $\begin{array}{c}\text { Average porosity } \\
\text { of the casting }\end{array}$ & $\begin{array}{l}\text { Internal } \\
\text { samples }\end{array}$ & $\begin{array}{l}\text { External } \\
\text { samples }\end{array}$ & $\begin{array}{c}\text { Average porosity } \\
\text { of the casting }\end{array}$ \\
\hline \multirow{4}{*}{$\mathrm{AlMg} 9$} & 3.67 & 1.85 & \multirow{4}{*}{2.83} & 1.28 & 1.53 & \multirow{4}{*}{1.50} \\
\hline & 4.13 & 1.43 & & 1.47 & 1.87 & \\
\hline & 3.23 & 1.78 & & 1.89 & 1.06 & \\
\hline & 4.58 & 1.95 & & 1.34 & 1.57 & \\
\hline \multirow{4}{*}{ AlSi7Mg } & 2.89 & 1.57 & \multirow{4}{*}{2.10} & 1.48 & 1.36 & \multirow{4}{*}{1.26} \\
\hline & 2.47 & 1.69 & & 1.03 & 1.02 & \\
\hline & 3.14 & 1.22 & & 1.25 & 1.58 & \\
\hline & 2.57 & 1.28 & & 1.21 & 1.14 & \\
\hline \multirow{4}{*}{$\mathrm{AlCu} 4 \mathrm{Ti}$} & 4.11 & 1.26 & \multirow{4}{*}{2.72} & 1.13 & 1.12 & \multirow{4}{*}{1.27} \\
\hline & 3.89 & 1.97 & & 1.58 & 1.02 & \\
\hline & 4.25 & 1.14 & & 1.36 & 0.98 & \\
\hline & 3.47 & 1.68 & & 1.74 & 1.26 & \\
\hline
\end{tabular}

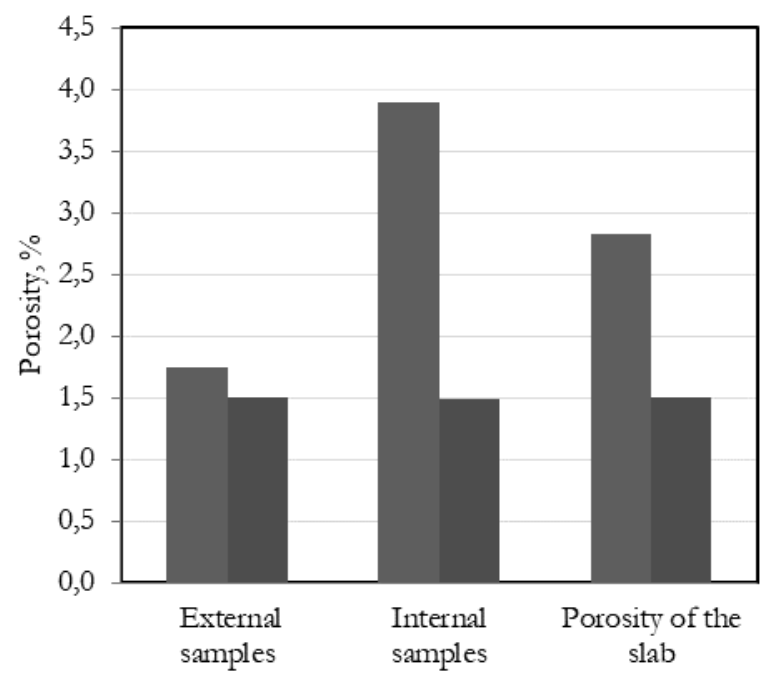

- The gravitational method $\quad$ The squeeze casting method Fig. 5 The average porosity of castings from AlMg9 alloy

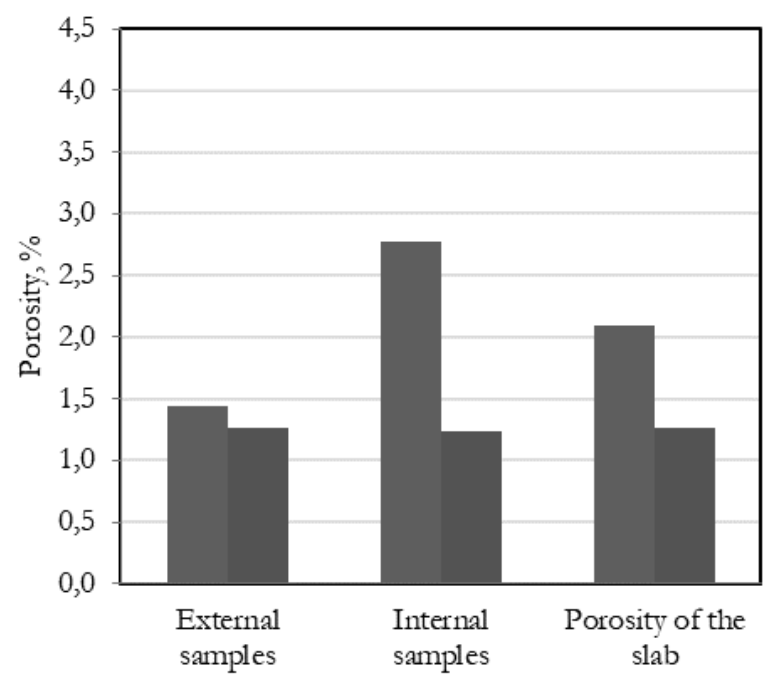

The gravitational method $\quad$ The squeeze casting method Fig. 6 The average porosity of castings from AlSi7Mg alloy 


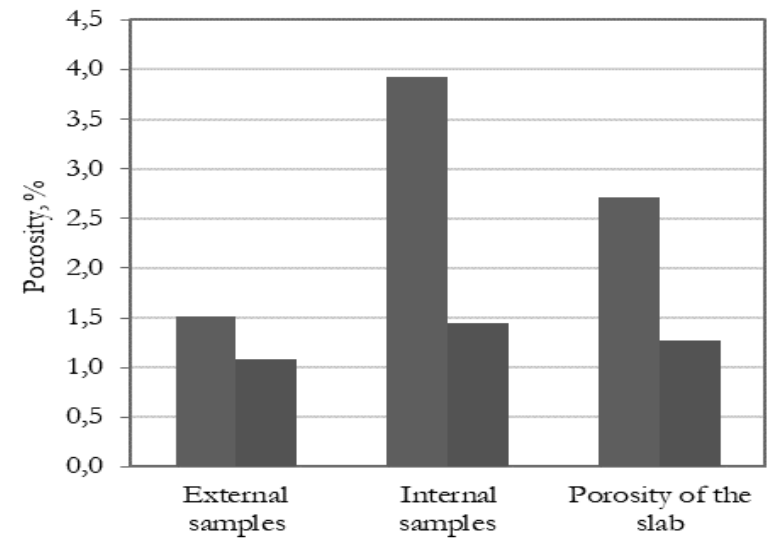

- The gravitational method $\mid$ The squeeze casting method
Pressing significantly reduces the porosity of castings made from all $\mathrm{Al}$ alloys. The beneficial effect of the applied pressure is especially visible in the central regions of the castings. In the $\mathrm{AlMg} 9$ and $\mathrm{AlCu} 4 \mathrm{Ti}$ alloys, the porosity in internal samples decreases from about $4 \%$ to $1.5 \%$. In the case of external samples, the porosity is also low, but its changes are at the level of $0.5 \%$. A further part of the research was the structural assessment of the castings of the aluminum alloy slab. Photographs of typical structures of gravitational and squeezed castings, revealing local microporosity are shown in Figure 8. Metallographic tests were performed in the central parts of the internal and external samples (Fig. 3).

Fig. 7 The average porosity of castings from AlCu4Ti alloy

Gravity castings
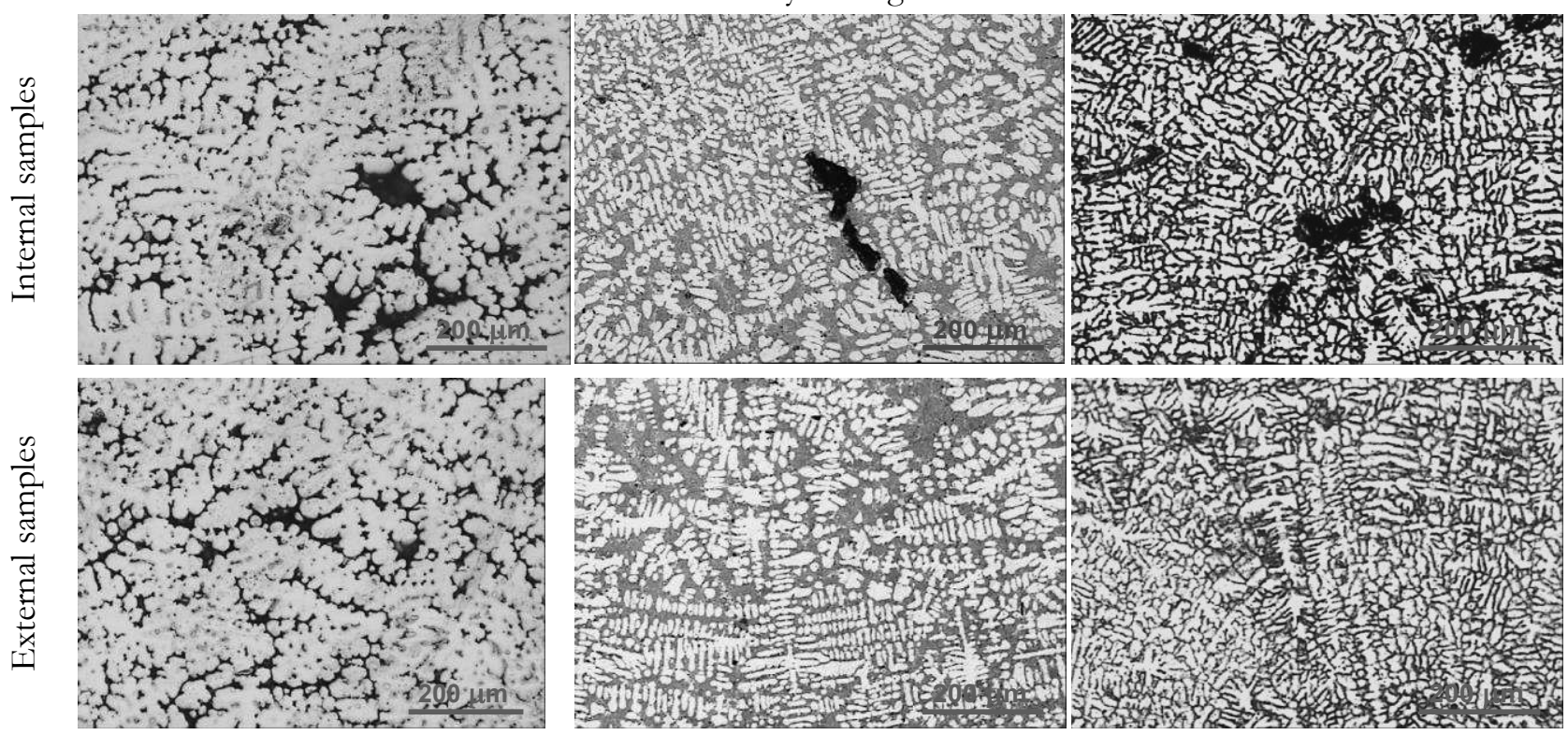

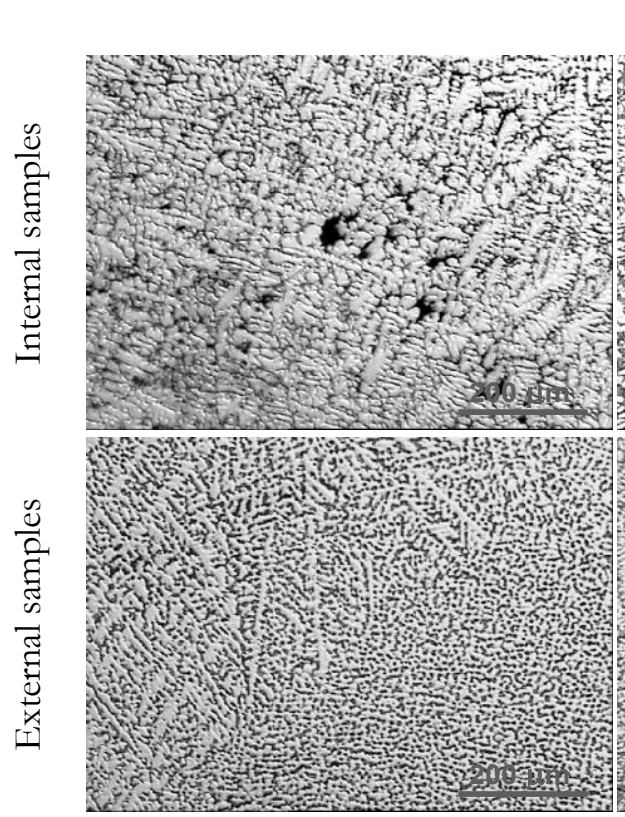

$\mathrm{AlMg} 9$

Squeeze casting castings
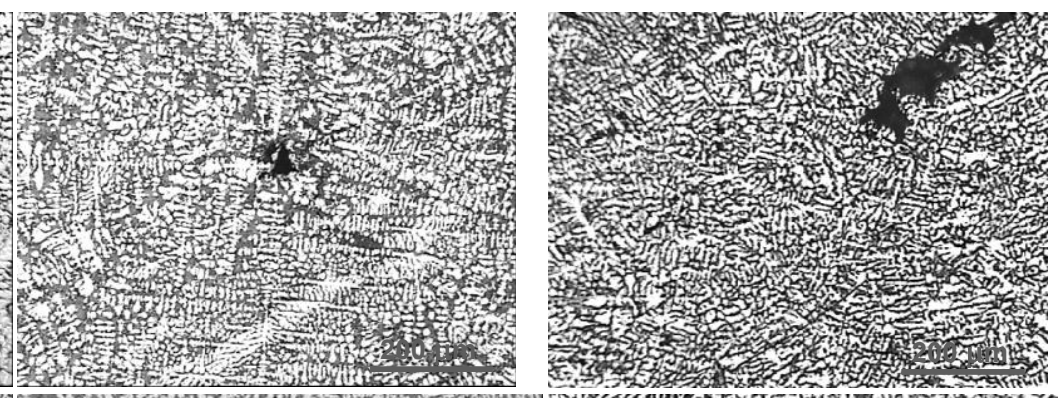

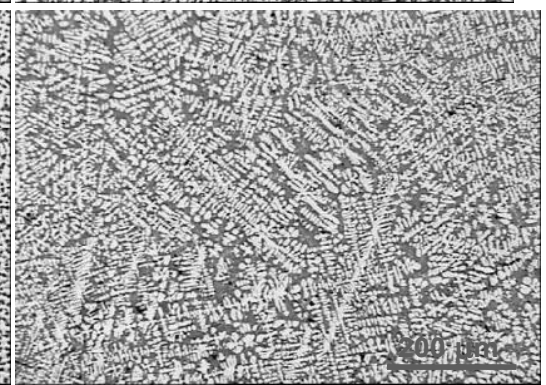

$\mathrm{AlSi} 7 \mathrm{Mg}$

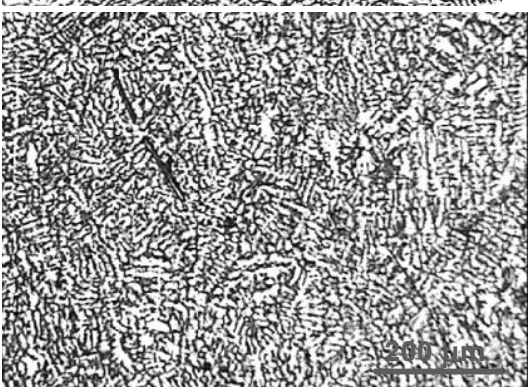

$\mathrm{AlCu} 4 \mathrm{Ti}$

Fig. 8 Structure and porosity of the tested aluminum alloys 
As reported by Fleming [25], shrinkage porosity and gas porosity may be present in aluminum alloy castings. Shrinkage porosity is determined by the shape of the casting, casting technology and the chemical composition of the alloy, while gas porosity is caused by low solubility of gases, mainly hydrogen, in the solidified alloy. The solubility of hydrogen in liquid aluminum is 10 times greater than in the solid state [26]. The shrinkage voids show an irregular shape and are scattered, unlike the gas voids, which have regular shape, mostly spherical, and are concentrated.

Shrinkage pores were created in all tested aluminum alloys, while the typical spherical gas voids were found only in the gravity cast AlMg9 alloy (Fig 9). Gas porosity was not revealed in the castings produced by squeeze casting. The condition for the formation of gas bubbles was presented by Felicelli et al. [27]:

$$
P_{G} \geq P_{0}+\rho_{l} g h+\left(\frac{2 \gamma_{g l}}{r}\right)[P a],
$$

Where:

$P_{g}$ - minimum internal gas pressure for the formation of stable bubble (Sievert's gas pressure), $\rho g h$ - metallostatic pressure, $2 \gamma_{g l} / r$ - pressure due to surface tension, $P_{0}-$ applied pressure.

Equation (4) states that, for the creation of a gas bubble the minimum internal pressure of the bubble must be greater than the external pressure. Since the high applied pressure increases the minimum gas pressure necessary to form a stable bubble, the gas porosity in squeeze casting is reduced.

The results of metallographic tests are consistent with the results of measurements obtained by the hydrostatic weighing method. Micropores are mainly found in internal samples taken from gravity casts. In the AlMg9 alloy, the shrinkage porosities have multiple arms and belong to several cavities. In the $\mathrm{AlCu} 4 \mathrm{Ti}$ alloy, shrinkage voids also belong to several cavities but their shape is more regular. In the case of the AlSi7Mg alloy, the shrinkage porosities are concentrated and have no developed arms. Applying pressure to the casting process caused the metal to flow into the interdendritic regions in the mushy zone. As a result, the shrinkage porosity of the castings was significantly compensated.

The effect of the applied pressure in the squeeze casting process on the size of the voids is presented in Fig. 10. The mean pores diameter in AlCu4Ti castings produced in the squeeze casting process are twice smaller than in gravity castings. In castings made of AlSi7Mg and AlMg9 alloys, the pore size is reduced by about 4-5 times. The mean diameter (D) of the pores was determined by measuring their length (L) and width (W). In the case of dendritic voids, the width was evaluated by measuring the smallest $\left(\mathrm{W}_{1}\right)$ and largest $\left(W_{2}\right)$ arm (Fig. 10) $-\mathrm{D}=\frac{1}{2}\left(\mathrm{~L}+\frac{\mathrm{W}_{1}+\mathrm{W}_{2}}{2}\right)$. According to the simulation predictions and the results of measurements by the hydrostatic weighing method, the shrinkage voids are concentrated in the central part of the castings. The exception is the AlMg9 alloy in which shrinkage porosity is also present in external regions of gravity castings.

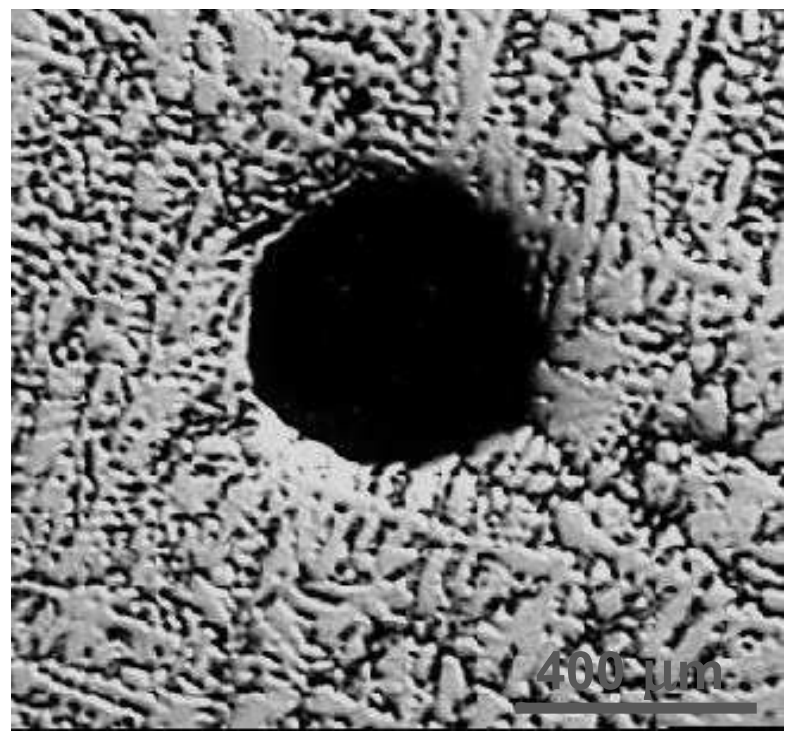

Fig. 9 Gas bubble in the gravity cast AlMg9 alloy

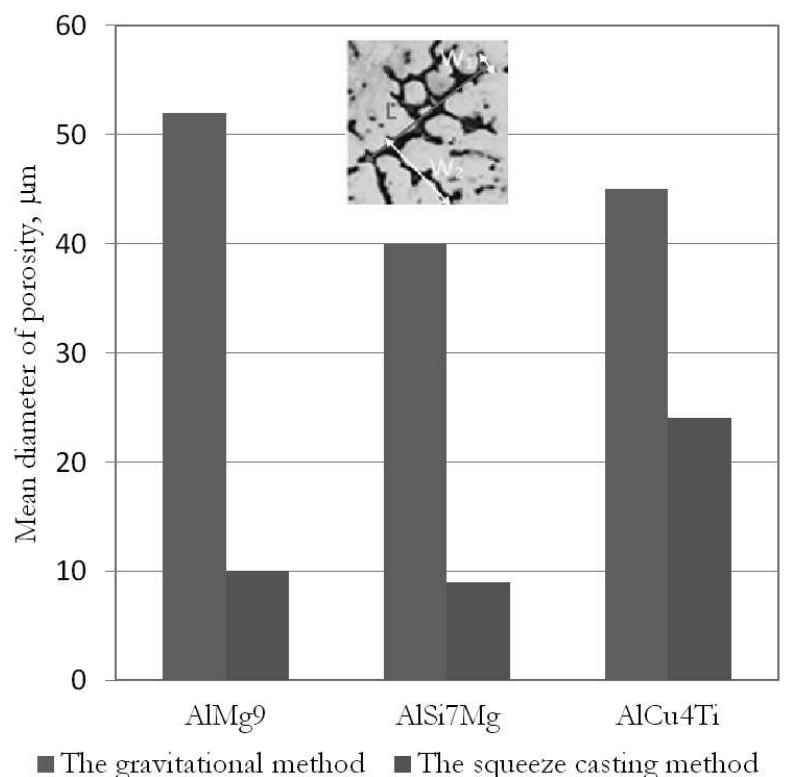

Fig. 10 Variation of pore diameter in aluminum alloys castings

\section{Discussion of research results}

The aim of the research was to assess the impact of the pressing pressure on the porosity of castings from aluminum alloys, taking into account its distribution in slab casts. Numerical simulations of solidification showed that the area particularly exposed to the occurrence of shrinkage phenomena is the middle part 
of the slab and the zone extending from the center of the slab to its upper surface. The results of the solidify simulation were confirmed by measurements of porosity and structural studies of casts. The basic statement resulting from the conducted research is that the squeeze casting technology effectively reduces the porosity in the slab castings for all analyzed grades of aluminum alloys. The lower porosity of gravity casts made of AlSi7Mg alloy, as well as the less visible impact of pressing on the limitation on the material voids in castings from this alloy are associated with its good technological properties. The linear shrinkage of the AlSi7Mg alloy is about $1 \%$, while the other alloys are at the level of $1.5-2.0 \%$. During the solidification of the AlSi7Mg alloy, the formation of the primary phase $\alpha(\mathrm{Al})$ decrease the volume of the casting, while the silicon that precipitates in eutectic cells causes its increase. Silicon increases its volume by $8 \%$ during the change of physical state [28]. Therefore, the total solidification shrinkage of this alloy is much smaller than other alloys.

Microstructural studies showed that shrinkage porosity occurs mainly in the analyzed $\mathrm{Al}$ alloys. Gas porosity was revealed only in $\mathrm{AlMg} 9$ gravity castings. The formation of gas bubbles in this alloy is explained by the addition of magnesium to the aluminum alloy. Magnesium increases the solubility of hydrogen in aluminum alloys. As reported by P.N. Anyalebechi [26], the solubility of hydrogen in pure aluminum at $700^{\circ} \mathrm{C}$ and $101.3 \mathrm{kPa}$ partial pressure is $0.8 \times 10^{-4}$ wt. $\% \mathrm{H}$. In the liquid AlMg6 alloy, the hydrogen solubility increases up to $2.2 \times 10^{-4}$ wt. $\% \mathrm{H}$. In contrast, copper and silicon in aluminum alloys reduce the solubility of hydrogen. For comparison, the solubility of hydrogen in the $\mathrm{AlCu} 4$ alloy is $0.35 \times 10^{-4}$ wt. $\% \mathrm{H}$ and in AlSi7 alloy it is equal to $0.55 \times 10^{-4} \mathrm{wt}$. $\% \mathrm{H}$ [26]. With regard to the AlMg9 alloy, it can therefore be concluded that applying pressure to the casting process allows for the elimination of gas bubbles.

The shrinkage porosities are the most numerous and scattered in the pressureless cast $A l M g 9$ and $\mathrm{AlCu} 4 \mathrm{Ti}$ alloys. Moreover, in the $\mathrm{AlMg} 9$ alloy, the shape of the voids is the most irregular. The formation of scattered shrinkage porosity is caused by the wide temperature range of solidification of the tested alloys and the morphology of their solidification. AlMg9 and $\mathrm{AlCu} 4 \mathrm{Ti}$ alloys have a dendritic structure with a small amount of double eutectic respectively $\left(\alpha+\mathrm{Al}_{8} \mathrm{Mg}_{5}\right)$ and $\left(\alpha+\mathrm{Al}_{2} \mathrm{Cu}\right)$. Micropores are located around the primary crystals in the interdendritic spaces and are formed in the final solidification stage due to the lack of supply of liquid metal. AlSi7Mg alloy has a twophase structure consisting of $\alpha$-phase dendrites and a silicon eutectic. In the case of this alloy, the shrinkage voids are less numerous and more concentrated and their shape is close to regular. In all the alloys tested, increased porosity was revealed on samples taken from the central parts of gravity cast slabs. Applying pressure to the casting process results in the flow of liquid metal into the interdendritic regions and an effective reduction of shrinkage porosity. Moreover, the squeeze casting allows for local plastic deformation of the casting and closing the micropores. Cherif et al. [29] was analyzed effect of squeeze casting pressure $(0.1-150 \mathrm{MPa})$ on microstructure and mechanical properties of recycled AlSiMg alloy. They showed that small and few microporosity and high mechanical properties of this alloy are obtained by implementing the squeeze casting process at $100 \mathrm{MPa}$ pressure. When assessing the influence of pressure on solidification of castings, it can be concluded that in all alloys there was a clear fragmentation of dendrites and, additionally, the distance between the secondary dendrite arm spacing was reduced (Fig. 8). This is the result of a faster heat dissipation from the mould during casting pressings and a greater tendency of the alloys to nucleation the primary phases under high pressure conditions. Higher intensity of heat dissipation is caused by the lack of a shrinkage gap between the pressed casting and the mould. During the pressing, the casting being in the liquid-solid state can plastically deform and adhere tightly to the surface of the mold cavity. The reduction of grain size and SDAS as well as the increase in grains boundaries density in high pressure solidification castings has been shown in [13, 29, 30] also comparing gravity casting technology with squeeze casting technology. In addition, gravitational castings have a heterogeneous structure in which there are three regions: "skin" area, "basaltic" area and "equiaxed" area [31]. Applying high pressure during solidification allows to obtain a homogeneous structure of castings. Al alloys used in research are often subjected to heat treatment (aging and supersaturation) in order to increase mechanical properties. The direct compression technology produces fine-grained castings with a very low microporosity that can be heat treated [30, 32] in contrast to castings made in competitive high pressure die casting technology. Therefore, it can also be dedicated to the production of responsible elements from $\mathrm{Al}$ alloys characterized by high mechanical properties, high tightness and the possibility of a calving treatment.

\section{Conclusion}

1. In the analyzed slab cast, the area particularly susceptible to shrinkage porosity is its central part and the zone extending from its center to the upper surface.

2. The $\mathrm{AlMg} 9$ and $\mathrm{AlCu} 4 \mathrm{Ti}$ alloys show a greater tendency to shrinkage porosity formation than the AlSi7Mg alloy. The shape of the shrinkage voids is the most irregular in the AlMg9 alloy. 
3. Squeeze casting mainly reduces shrinkage porosity in the center of the slab. In AlMg9 and $\mathrm{AlCu} 4 \mathrm{Ti}$ alloys castings, porosity in these areas decreases threefold, while in AlSi7Mg alloy castings more than twice.

4. The average porosity of castings made by squeeze casting is twice lower than casts produced by gravity and is at the level of 1.0$1.5 \%$ depending on the type of alloy. In addition, the distribution of porosity is fairly uniform throughout the castings.

5. Applying pressure to the casting process reduces the pore size. The greatest changes in the pore diameter size occur in the AlMg9 and $\mathrm{AlSi} 7 \mathrm{Mg}$ alloys

6. The impact of high pressure $(90 \mathrm{MPa})$ during solidification of $\mathrm{AlMg} 9, \mathrm{AlCu} 4 \mathrm{Ti}$ and AlSi7Mg alloys results in reduction of grains size and distance between the secondary dendrite arm spacing.

\section{References}

[1] SOBCZAK, J. (1993). Theoretical and practical foundations of liquid state squeeze casting processes for non-ferrous metals. In: Transactions of Foundry Research Institute, Vol. 41, pp. 161-236.

[2] SOBCZAK, J., DRENCHEV, L., ASTHANA, R. (2012). Effect of pressure on solidification of metallicmaterials. In: International Journal of Cast Metals Research, Vol. 25, pp. 1-14.

[3] HAJDASZ, M., DROZDOWSKI, R., DUNIANAZAR, T., WINNICKI, Z. (1996). A device for testing metal barocrystallization. In: Scientific Journals of the Maritime University of Szrzecin, Vol. 52, pp. 25-31.

[4] GHOMASHCHI, M. R., VIKHROV, A.(2000). Squeeze casting: an overview. In: Journal of Materials Processing Technology, Vol. 101, pp. 1-9.

[5] ZHANG, W., ZHAO, Y., ZHANG, D., LUO, Z., YANG Ch., LI, Y. (2018). Effect of Si addition and applied pressure on microstructure and tensile properties of as-cast $\mathrm{Al}-5.0 \mathrm{Cu}-0.6 \mathrm{Mn}-1.2 \mathrm{Fe}$ alloys. In: Transactions of Nonferrous Metals Society of China, Vol. 28, pp. 1061-1072.

[6] SCHWAM, D., WALLACE, J. F., CHANG, Q., ZHU, Y. (2002). Optimization of the squeeze casting process for aluminum alloy parts. In: US Department of Energy Assistant Secretary for Energy Efficiency and Renewable Energy, p.5, Washington D.C.
[7] ZYSKA, A., KONOPKA, Z., ŁĄGIEWKA, M., NADOLSKI, M. (2013). Optimization of Squeeze Parameters and Modification of AlSi7Mg Alloy. In: Archives of Foundry Engineering, Vol. 13, pp. 113-116.

[8] CAMPBELL, J. (2011). Complete casting, Handbook, Metal Casting Processes, Metallurgy, Tecbnique sand Design, pp. 142-185. Butterworth-Heinemann, Elsevier.

[9] DUDEK, P. (2017). Application of squeeze casting technology to obtain aluminum alloy castings. In: Transactions of Foundry Research Institute, Vol. 58, pp. 211-224.

[10] CHATTOPADHYAY, H. (2007). Simulation of transport processes in squeeze casting. In: Journal of Materials Processing Technology, Vol. 186, pp. 174-178.

[11] AHMAD, R., GETHIN, D.T., LEWIS, R.W.(2012). Design Element Concept of squeeze casting process. In: Applied Mathematical Modelling, Vol.36, pp. 4760-4788.

[12] PENNINGTON, J.N. (1988). Squeeze-cast parts approach performance of forgings. In: Modern Metal Vol. 44, pp. 52-60.

[13] ZYSKA, A., KONOPKA, Z., ŁA_GIEWKA, M., NADOLSKI, M. (2010). Characteristics of squeeze cast $\mathrm{AlZn} 5 \mathrm{Mg}$ alloy castings. In: Archives of Metallurgy and Materials, Vol. 55, pp. 969-975.

[14] YANG, L.J. (2003). The effect of casting temperature on the properties of squeeze cast aluminium and zinc alloys. In: Journal of Materials Processing Technology, Vol. 140, pp. 391-396.

[15] ABOU EL-KHAIR, M.T. (2005). Microstructure characterization and tensile properties of squeeze-cast AlSiMg alloys. In: Materials Letters, Vol. 59, pp. 894- 900.

[16] WANG, F., MA, Q., MENG, W., HAN, Z. (2017). Experimental study on the heat transfer behavior and contact pressure at the castingmold interface in squeeze casting of aluminum alloy. In: International Journal of Heat and Mass Transfer, Vol. 112, pp. 1032-1043.

[17] HAN, ZH., HUANG, X., LUO, A., SACHDEV, A., LIU K.B. (2012). A quantitative model for describing crystal nucleation in pressurized solidification during squeeze casting. In: Scripta Materialia, Vol. 66, pp. 215-218.

[18] PASTIRCAK, R., MARTINEC, D., KANTORIKOVA, E. (2020). Influence of Semisolid Squeeze Casting Technology on Alpha 
Phase and Eutectic of AlSi7Mg0.3. In: Manufacturing Technology, Vol. 20, pp. 78-83.

[19] KUCHARIKOVÁ, L., TILLOVÁ, E., PASTIR Č ÁK, R., UHRÍ Č IK, M., MEDVECKÁ, D. (2019). Effect of Wall Thickness on the Quality of Casts from Secondary Aluminium Alloy. In: Manufacturing Technology, Vol. 19, pp. 797-801.

[20] MAJERNIK, J., GASPAR, S., GRYC, K., SOCHA, L. (2018). Changes in Eutectic Silumin Structure Depending on Gate Geometry and Its Effect on Mechanical Properties of Casting. In: Manufacturing Technology, Vol. 18, pp. 439-443.

[21] PODPROCKA, R., BOLIBRUCHOVA, D. (2018). The Role of Manganese in the Alloy Based on Al-Si-Mg with Higher Iron Content. In: Manufacturing Technology, Vol. 18, pp. 650-654.

[22] HREN, I., SVOBODOVA, J., MICHNA, Š. (2019). Analysis of Microstructure Changes for AlSi7Mg0.3 Alloy Caused by Modification. In: Manufacturing Technology, Vol. 19, pp. 767771.

[23] SENTHIL, P., AMIRTHAGADESWARAN, K. S. (2013). Experimental Study and Squeeze Casting Process Optimization for High Quality AC2A Aluminium Alloy Castings. In: Arabian Journal for Science and Engineering, Vol. 39, pp. 2215-2225.

[24] PATEL, M.G.C., KRISHNA, P., PARAPPAGOUDAR, M.B. (2015). Prediction of Secondary Dendrite Arm Spacing in Squeeze Casting Using Fuzzy Logic Based Approaches. In: Archives of Foundry Engineering, Vol. 15, pp. 51-68.

[25] FLEMING, M.C. (1974). Solidification processing. In: Metallurgical Transactions B, Vol. 5, pp. 2121-2134.
[26] ANYALEBECHI, P.N. (1998). Analysis and thermodynamic prediction of bydrogen solution in solid and liquid multicomponent aluminum alloys, pp. 827842. Light Metals, , The Minerals, Metals and Materials Society, Barry Welch.

[27] FELICELLI, S.D., POIRIER, D.R., SUNG, P.K. (2000). A Model for Prediction of Pressure and Redistribution of Gas-Forming Elements in Multicomponent Casting Alloys. In: Metallurgical and Materials Transactions B, Vol. 31B, pp. 1283-1292.

[28] GÓRNY, Z., Metals and alloys casting. Special casting methods -Vol. III, pp.152-178. Foundry Research Institute, Kraków.

[29] CHÉRIF, A., SOUISSI, S., BEN AMAR, M., BRADAI, CH., KHITOUNI, M. (2017). Effect of squeeze casting pressure on microstructure and mechanical properties of recycled aluminum alloy. In: Journal of the Tunisian Chemical Society, Vol. 19, pp. 198-207.

[30] SOUISSI, N., SOUISSI, S., LE NINIVEN, C., BEN AMAR, M., BRADAI, C., ELHALOUANI, F.(2014). Optimization of squeeze casting parameters for 2017 a wrought al alloy using Taguchi method. In: Metals, Vol. 4, pp. 141-154.

[31] GOURGUES-LORENZON, A.F., HAUDIN, J.M.(2010). Matériaux pour l'ingénieur, pp.81-92, Ecole des Mines, Paris.

[32] SOUISSI, S., SOUISSI, N., BARHOUMI, H., BEN AMAR, M., BRADAI, C., ELHALOUANI, F. (2019). Characterization of the Role of Squeeze Casting on the Microstructure and Mechanical Properties of the T6 Heat Treated 2017A Aluminum Alloy. In: Advances in Materials Science and Engineering, Vol. 2019, pp. 19. 